\title{
Metabolites from Roots of Colubrina greggii var. yucatanensis and Evaluation of their Antiprotozoan, Cytotoxic and Antiproliferative Activities
}

\author{
Dafne B. Domínguez-Carmona, ${ }^{a}$ Fabiola Escalante-Erosa, ${ }^{a}$ Karlina García-Sosa,${ }^{a}$ \\ Grace Ruiz-Pinell, ${ }^{b}$ David Gutierrez-Yapu, ${ }^{b}$ Manuel J. Chan-Bacab, ${ }^{c}$ Rosa E. Moo-Puc, ${ }^{d}$ \\ Nigel C. Veitch, ${ }^{e}$ Alberto Giménez-Turba ${ }^{b}$ and Luis M. Peña-Rodríguez, ${ }^{* a}$ \\ ${ }^{a}$ Unidad de Biotecnología, Centro de Investigación Científica de Yucatán. \\ Calle 43, N. 130, Col. Chuburná, Mérida, Yucatán, 97200 México \\ ${ }^{b}$ Instituto de Investigaciones Fármaco-Bioquímicas, Universidad Mayor de San Andrés, \\ Av. Saavedra 2224, La Paz, Bolivia \\ 'Departamento de Microbiología Ambiental y Biotecnología, Universidad Autónoma de Campeche, \\ Agustín Melgar s/n, Campeche, Campeche, México \\ ${ }^{d}$ Unidad de Investigación Médica Yucatán, Unidad Médica de Alta Especialidad, Centro Médico \\ Ignacio García Téllez IMSS, Calle 41, N. 439, Col. Industrial, Mérida, Yucatán, 97150 México
}

eJodrell Laboratory, Royal Botanic Gardens Kew, Richmond, Surrey, TW9 3AB UK

\begin{abstract}
A purificação do extrato da raiz de Colubrina greggii var. yucatanensis levou ao isolamento e identificação do ácido 3-O-acetil ceanótico, um novo triterpeno natural, juntamente com os metabólitos já descritos: ácido ceanótico, ácido cenoténico, ácido betulínico, discarina B e crisofaneína. Os produtos naturais e os derivados semi-sintéticos éster de acetil dimetil ceanotato, dimetil ceanotato e peracetato de crisofaneína mostraram moderada a baixa atividade leishmanicida e tripanocida. Nenhum dos metabólitos mostrou ser citotóxicos ou ter atividade antiproliferativa. Os resultados também sugerem que o ácido betulínico contribui para a atividade antiplasmódica inicialmente detectada na raiz do extrato bruto de C. greggii var. yucatanensis.
\end{abstract}

Purification of the root extract of Colubrina greggii var. yucatanensis resulted in the isolation and identification of 3-O-acetyl ceanothic acid as a new natural ceanothane triterpene, together with the known metabolites ceanothic acid, cenothenic acid, betulinic acid, discarine B and chrysophanein. The natural products and the semisynthetic esters acetyl dimethyl ceanothate, dimethyl ceanothate and chrysophanein peracetate showed moderate to low leishmanicidal and trypanocidal activities. None of the metabolites showed cytotoxic or antiproliferative effects. The results also suggested that betulinic acid contributes to the antiplasmodial activity originally detected in the crude root extract of $C$. greggii var. yucatanensis.

Keywords: Colubrina greggii var. yucatanensis, Rhamnaceae, antiprotozoan, cytotoxic ceanothane

\section{Introduction}

Leishmaniosis, trypanosomiosis and malaria are a group of protozoan diseases considered of significant importance due to their incidence and rate of mortality in developing countries. ${ }^{1}$ The low effectiveness, limited availability and high toxicity of existing treatments for these illnesses emphasize

*e-mail: 1manuel@cicy.mx the importance of continuing the search for new antiprotozoan pharmaceuticals. ${ }^{2}$ Plants are considered an important source of biologically active natural products, ${ }^{3}$ including a number of them with antiprotozoan activity. ${ }^{4-6}$ During the screening of extracts from native Yucatecan medicinal plants as potential sources of bioactive metabolites, the root extract of Colubrina greggii S. Watson var. yucatanensis M. C. Johnst., a shrub used for the treatment of liver diseases, ulcerations, abscesses, asthma and tuberculosis, ${ }^{7}$ showed 
trypanocidal, antimalarial, leishmanicidal and cytostatic activity. ${ }^{8,9}$ Previous phytochemical studies of the genus Colubrina (Rhamnaceae), which include 31 species, ${ }^{10}$ reported the presence of a wide structural diversity of metabolites, including ansa macrolides, saponins, aporphinic alkaloids, phenolic acids, flavones and triterpenoid acids. ${ }^{11-18}$ To date, only chrysophanol, an anthraquinone with antimicrobial activity, has been reported as a metabolite from C. greggii. ${ }^{19}$ In the present study we report the leishmanicidal, trypanocidal, antiplasmodial, cytotoxic and antiproliferative activity of the crude extract, semi-purified fractions and isolated metabolites from the root extract of $C$. greggii var. yucatanensis.

\section{Results and Discussion}

Fractionation of the bioactive root extract of $C$. greggii var. yucatanensis yielded a low polarity fraction with leishmanicidal, trypanocidal and antiplasmodial activities and a medium-polarity fraction with leishmanicidal activity. Successive purification of the medium-polarity fraction resulted in the isolation of 3-O-acetyl-ceanoth20(30)-en-1,28-dioic acid (3-O-acetyl ceanothic acid) (1) as a new natural ceanothane triterpene, together with the known metabolites ceanothic acid (2), discarine B (5) and chrysophanein (6). Similarly, purification of the lowpolarity fraction led to the isolation and identification of ceanothenic acid (3) and betulinic acid (4) (Figure 1).
The FTIR spectrum of $\mathbf{1}$ showed absorption bands at 3073 $(\mathrm{CH}=\mathrm{C}), 1731$ (ester) and $1681 \mathrm{~cm}^{-1}$ (carboxyl). The pseudo molecular ion peak $[\mathrm{M}+\mathrm{Na}]^{+}$at $m / z 551.3524$ in HRMS (high resolution mass spectrometry) indicated a molecular formula $\mathrm{C}_{32} \mathrm{H}_{48} \mathrm{O}_{6}$, implying nine degrees of unsaturation. Carbon multiplicity, deduced from HMQC (heteronuclear multiple quantum coherence) and DEPT (distortionless enhancement by polarization transfer) experiments, indicated the presence of seven methyl groups, nine methylene, seven methine, and nine quaternary carbons. The ${ }^{1} \mathrm{H}$ NMR spectrum of $\mathbf{1}$ (Table S1, Figure S1) displayed seven three-proton singlets at $\delta 0.88$, $0.98,0.99,1.06,1.16,1.68$ and 2.03 consistent with methyl groups attached to quaternary carbons. The presence of an acetyl group was confirmed by the HMBC (heteronuclear multiple bond coherence) correlation of the methyl at $\delta 2.03$ with the carbonyl at $\delta 172.5$, whereas an isopropenyl group was assigned from NMR signals corresponding to a methyl group $\left(\delta_{\mathrm{H}} 1.68\right)$ attached to a $s p^{2}$-carbon $\left(\delta_{\mathrm{C}} 152.0\right)$ showing HMBC correlations with two vinylic protons at $\delta_{\mathrm{H}} 4.58$ and $\delta 4.70$. The double bond and three carbonyl groups observed in the ${ }^{13} \mathrm{C}$ NMR of $\mathbf{1}(\delta 172.5,177.4$ and 180.1) accounted for four degrees of unsaturation thus indicating that the five remaining unsaturation sites corresponded to a pentacyclic structure. The spectroscopic data of $\mathbf{1}$ proved to be very similar to those reported for ceanothic acid (2), a ceanothane triterpene also known as emmolic acid, originally isolated from Ceanothus americanus ${ }^{20}$ and later identified from Colubrina granulosa. ${ }^{13}$ However, the presence of a
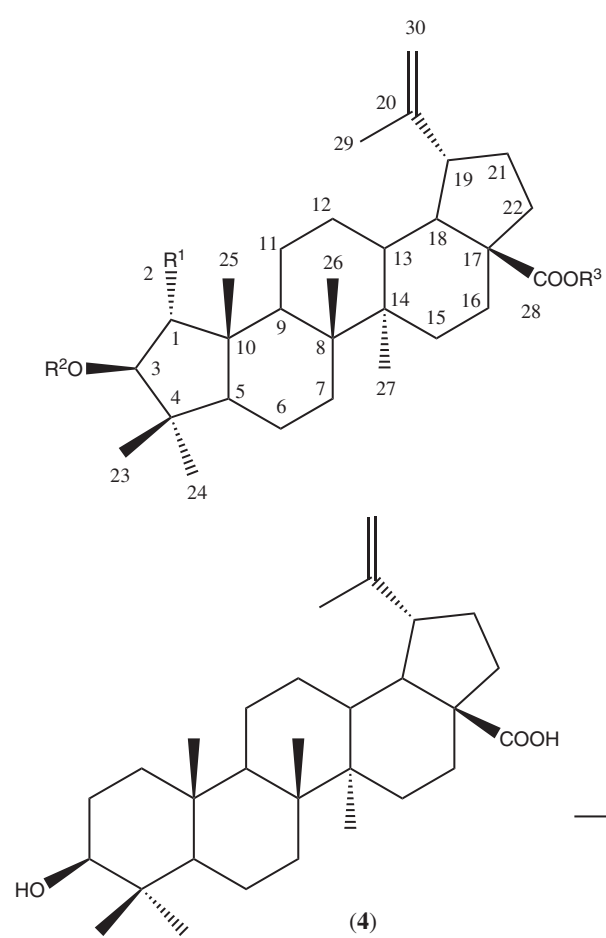

(4)
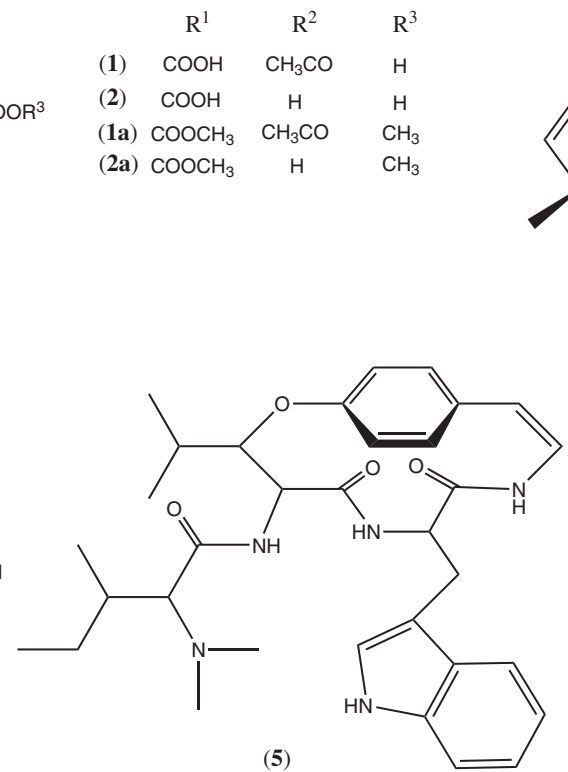

(5)

Figure 1. Structures of natural products 1-6 isolated from $C$. greggii, and semisynthetic derivatives 1a, 2a and 6a.

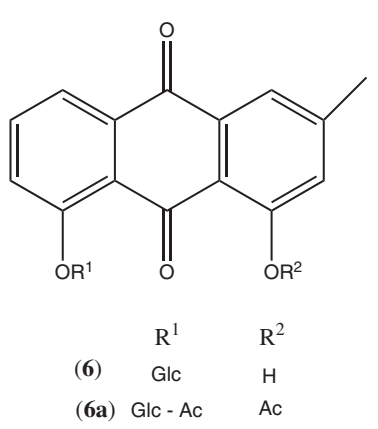

(6a) Glc-Ac Ac 
low-field carbinol proton $(\delta 5.07)$ and an acetyl methyl singlet $(\delta 2.03)$ in the ${ }^{1} \mathrm{H}$ NMR spectrum of $\mathbf{1}$, both showing strong HMBC correlations with the ester carbonyl carbon $(\delta 172.5)$, suggested that $\mathbf{1}$ was the 3-O-acetyl derivative of ceanothic acid, which was confirmed when acetylation of $\mathbf{2}$ produced $\mathbf{1}$ as the only product. The presence of $\mathbf{1}$ in the original root extract of $C$. greggii, as detected by TCL (Figure S2), ruled out its being an artifact of the isolation procedure.

Discarine B (5), chrysophanein (6) and ceanothenic acid (3) were identified from comparison of their spectroscopic data (Tables S1, S2 and S3) with those reported in literature..$^{21-23}$ Betulinic acid (4) was identified by comparison with an authentic sample. ${ }^{24}$

All of the isolated metabolites and the semisynthetic esters acetyl-dimethyl ceanothate (1a), dimethyl ceanothate (2a) and chrysophanein peracetate (6a) were evaluated for their in vitro antiprotozoan (leishmanicidal, trypanocidal, and antiplasmodial), cytotoxic and antiproliferative activities (Table 1). The results showed a moderate leishmanicidal activity $\left(\mathrm{IC}_{50}\right.$ values of $20-28 \mu \mathrm{g} \mathrm{mL}^{-1}$ ) for natural ceanothanes $\mathbf{1}$ and $\mathbf{3}$ and semisynthetic derivatives 2a and 6a, whereas a low trypanocidal activity $\left(\mathrm{IC}_{50}\right.$ of 30-70 $\mu \mathrm{g} \mathrm{mL}^{-1}$ ) was observed for the natural products 3-5 and the semisynthetic esters 1a and 6a. Betulinic acid (4) appeared to contribute to the antiplasmodial activity of the crude extract of $C$. greggii, with an $\mathrm{IC}_{50}$ of $9.7 \mu \mathrm{g} \mathrm{mL}^{-1} .25,26$
Although the crude root extract, together with the low and medium polarity fractions showed cytotoxic activity against HEp-2 cells, none of the isolated metabolites displayed this type of activity (Table S4). Furthermore, none of the metabolites tested, with the exception of the peracetylated chrysophanein (6a), showed antiproliferative activity against $\mathrm{KB}$ cells (Table S5). It is interesting to point out that the cytotoxic activity of C. macrocarpa and C. texensis has been attributed to the presence of colubrinol and its acetate, ${ }^{11,27}$ however these metabolites were not detected in the root extract of $C$. greggii.

To date, ceanothane triterpenes have only been reported to occur in species of the Rhamnaceae family, ${ }^{20,23,28-36}$ and particularly in those belonging to the ziziphoids in the tribal classification reported by Richardson et al. ${ }^{38}$ These results, together with our finding of ceanothanes in the root extract of C. greggii, support the possible use of this class of triterpenes as chemotaxonomic markers for a classification of Rhamnaceae based on a phylogenetic analysis.

\section{Experimental}

\section{General}

Analytical TLC (thin layer chromatography) was carried out on aluminum-backed silica gel $\left(60 \mathrm{~F}_{254}\right)$ plates

Table 1. Leishmanicidal, trypanocidal, antiplasmodial and cytotoxic activity $\left[\mathrm{IC}_{50}\left(\mu \mathrm{g} \mathrm{mL}^{-1}\right)\right]$ of crude extract, semipurified fractions, natural products 1-6 and semisynthetic derivatives $1 \mathbf{a}, \mathbf{2 a}$ and $\mathbf{6 a}$

\begin{tabular}{|c|c|c|c|c|c|c|}
\hline \multirow{3}{*}{$\begin{array}{l}\text { Extract/ } \\
\text { Compound }\end{array}$} & \multicolumn{6}{|c|}{ Antiprotozoan activity } \\
\hline & \multicolumn{2}{|c|}{ L. amazonensis } & \multicolumn{2}{|c|}{ T. cruzi tulahuen } & \multirow{2}{*}{$\begin{array}{l}\text { P. falciparum } \\
\mathrm{IC}_{50}\end{array}$} & \multirow{2}{*}{$\begin{array}{l}\text { VERO } \\
\mathrm{IC}_{50}\end{array}$} \\
\hline & $\mathrm{IC}_{50}$ & SI & $\mathrm{IC}_{50}$ & SI & & \\
\hline CG-1 & 32.4 & - & $>100$ & - & 8.0 & NT \\
\hline CG-2A & $<25$ & - & 73.9 & - & 4.5 & NT \\
\hline CG-2B & $<25$ & - & $>100$ & - & $>10$ & NT \\
\hline 1 & $28.2 \pm 2.7$ & 3.6 & $>100$ & - & $>10$ & $103.1 \pm 1.8$ \\
\hline 2 & $46.4 \pm 8.4$ & 2.8 & $>100$ & - & NT & $131.2 \pm 3.2$ \\
\hline 1a & $40.2 \pm 9.8$ & - & $56.2 \pm 5.2$ & - & NT & NT \\
\hline $2 a$ & $20.6 \pm 6.8$ & - & $>100$ & - & NT & NT \\
\hline 3 & $22.1 \pm 2.7$ & 4.4 & $64.0 \pm 4.3$ & 1.5 & NT & $98.6 \pm 1.2$ \\
\hline 4 & $>100$ & - & $34.2 \pm 11.1$ & 4.2 & 9.7 & $145.0 \pm 2.9$ \\
\hline 5 & $>100$ & - & $56.2 \pm 3.2$ & 3.5 & $>10$ & $199.1 \pm 2.7$ \\
\hline 6 & $>100$ & - & $56.7 \pm 19.5$ & 9.1 & $>10$ & $521.0 \pm 6.3$ \\
\hline $6 a$ & $12.7 \pm 1.1$ & 9.7 & $65.3 \pm 9.0$ & 1.8 & $>10$ & $123.8 \pm 4.2$ \\
\hline PTM & $10.0 \pm 0.8$ & - & - & - & - & NT \\
\hline BZD & - & - & $7.4 \pm 0.5$ & - & - & NT \\
\hline CLQ & - & - & - & - & $0.1 \pm 0.02$ & NT \\
\hline
\end{tabular}

CG-1: crude extract of C. greggii; CG-2A: low polarity fraction; CG-2B: medium polarity fraction; PTM: pentamidine; BZD: benznidazole; CLQ: chloroquine; SI: selectivity index were calculated as the ratio $\mathrm{IC}_{50}$ of cytotoxic activity in $\mathrm{VERO}$ cells/ $/ \mathrm{IC}_{50}$ of antiprotozoan activity. 
(E.M. Merck, $0.2 \mathrm{~mm}$ thickness) and the chromatograms visualized using a solution of phosphomolybdic acid (20 g) and ceric sulfate $(2.5 \mathrm{~g})$ in $500 \mathrm{~mL}$ of sulfuric acid $(5 \%)$. Flash chromatography purifications were performed using silica gel (Aldrich, 200-400 mesh), while TLC-grade silica gel 60GF ${ }_{254}$ (E.M. Merck) was used for vacuum liquid chromatography (VLC). Prep-TLC purifications were carried out using glass plates impregnated with silica gel $60 \mathrm{~F}_{254}$ (E.M. Merck, $0.25 \mathrm{~mm}$ thickness, $20 \times 20 \mathrm{~cm}$ ). Melting points (uncorrected) were determined from a Mel-Temp II apparatus (Laboratory Devices Inc.). The optical rotations were measured in $\mathrm{CHCl}_{3}$ using a Perkin Elmer 341 polarimeter. FTIR (Fourier transform infrared) spectra were recorded in $\mathrm{CHCl}_{3}$ or $\mathrm{MeOH}$ (film) using an FT-Nicolet Magna Protégé 460 spectrophotometer. ${ }^{1} \mathrm{H}$ NMR (400 and $600 \mathrm{MHz}$ ) and ${ }^{13} \mathrm{C}$ NMR (100 and $150 \mathrm{MHz}$ ) spectra were acquired on a Bruker Avance 400 spectrometer or a Bruker Avance 600 spectrometer with $\mathrm{CHN}$ cryoprobe, using the residual solvent resonances as internal references, calibrated to TMS. Electrospray high-resolution mass spectra (ESI-HRMS) were determined by direct injection on a Waters Q-TOF microsystem (using $0.1 \%$ phosphoric acid in a 1:1 water/acetonitrile mixture as reference), or using an Orbitrap MS (Thermo) connected to a Surveyor HPLC (high-performance liquid chromatography, Thermo) for sample injection.

\section{Plant material}

Roots of Colubrina greggii S. Watson var. yucatanensis M. C. Johnst. were collected in Abalá, Yucatán, México. A voucher specimen (P. Simá-D. Domínguez 2916) was deposited in the Herbarium of Centro de Investigación Científica de Yucatán.

\section{Extraction of plant material and purification of crude extract}

Dry roots of $C$. greggii (365 g) were extracted three times with ethanol (4 L) at room temperature. Evaporation of the solvent yielded the corresponding crude extract (CG-1, $54.5 \mathrm{~g}, 14.9 \%$ ), which was suspended in $1.8 \mathrm{~L}$ of a $\mathrm{H}_{2} \mathrm{O} / \mathrm{MeOH}$ $(3: 2, v / v)$ mixture. The suspension was fractionated by successive liquid-liquid partition with hexane (three times; $2: 1,1: 1,1: 1 ; \mathrm{v}: \mathrm{v}$ of solvent:aqueous suspension), ethylacetate (three times; 2:1, 1:1, 1:1) and water-saturated butanol (1:2; v:v solvent:aqueous suspension) to yield the corresponding low (CG-2A), medium (CG-2B) and high (CG-2C) polarity fractions. Purification of the medium polarity fraction (CG-2B, 9.6 g) by VLC, using a gradient elution with $\mathrm{CH}_{2} \mathrm{Cl}_{2} / \mathrm{Me}_{2} \mathrm{CO}$ (99:1 to $94: 6$ ) followed by $\mathrm{CHCl}_{3} /$ hexane/MeOH (70:25:5), yielded fractions CG-5A-N. Fraction CG-5E (550 mg) was purified by flash chromatography using an isocratic elution with hexane/ $\mathrm{Me}_{2} \mathrm{CO} 8: 2$, to produce pure 3-O-acetyl-ceanothic acid (1, $172.1 \mathrm{mg}$ ), and fraction CG-6I (50 mg) which was further purified by column chromatography [ether/hexane (1:1)] to yield ceanothic acid $(2,16.5 \mathrm{mg})$. Additional purification of fraction CG-5C (414 mg) by flash chromatography, using a gradient elution with hexane/ $\mathrm{Me}_{2} \mathrm{CO}(8: 2-7: 3)$, resulted in the isolation of discarine B $(\mathbf{5}, 108 \mathrm{mg})$. Finally, chrysophanein $(6,168.5 \mathrm{mg})$ was collected as a yellow precipitate by filtration from fraction CG-5G. Purification of the low polarity fraction (CG-2A, $1.5 \mathrm{~g}$ ) by VLC, using a gradient elution with mixtures of hexane/ $\mathrm{Me}_{2} \mathrm{CO} / \mathrm{MeOH}$ (95:3:2 to 60:38:2), produced eleven fractions (CG-3A-K). Fractions CG-3E-F were combined (500 mg) and purified by flash chromatography (hexane/ether 7:3), to yield ceanothenic acid (3, $20.8 \mathrm{mg})$ and betulinic acid (4, $20.4 \mathrm{mg})$.

\section{3-O-acetyl-ceanothic acid (1)}

White amorphous solid; mp: 271.5-273.1 ${ }^{\circ} \mathrm{C}$; $[\alpha]_{\mathrm{D}}{ }^{20}+33.7^{\circ}$ (c $0.01, \mathrm{Me}_{2} \mathrm{CO}$ ); FTIR (film) $v_{\max } \mathrm{cm}^{-1}: 3073$ $(\mathrm{CH}=\mathrm{C}), 1731$ (ester), 1685 (carboxyl); ${ }^{1} \mathrm{H} \mathrm{NMR}\left(\mathrm{CD}_{3} \mathrm{OD}\right.$, $400 \mathrm{MHz})$ and ${ }^{13} \mathrm{C} \mathrm{NMR}\left(\mathrm{CD}_{3} \mathrm{OD}, 100 \mathrm{MHz}\right)$ data: see Table S1; ESI-HRMS m/z 551.3524 [M + Na] ${ }^{+}$(calc. for $\mathrm{C}_{32} \mathrm{H}_{48} \mathrm{NaO}_{6}$ : 551.3584).

\section{Ceanothic acid (2)}

White amorphous solid; $[\alpha]_{\mathrm{D}}{ }^{20}+30.8^{\circ}$ (c 0.003, $\mathrm{MeOH}$ ); FTIR (film) $v_{\max } \mathrm{cm}^{-1}: 3411(\mathrm{OH}), 1697$ (>C=O); ${ }^{1} \mathrm{H}$ NMR (CD $\left.30 D, 400 \mathrm{MHz}\right): \delta 0.88$ (s, 3H, H-24), 0.90 (s, 3H, H-26), 0.97 (s, 3H, H-27), 1.01 (s, 3H, H-25), 1.35 (s, 3H, H-23), 1.67 (s, 3H, H-29), 2.45 (s, 1H, H-1), 3.06 (m, 1H, H-19), 4.06 (s, 1H, H-3), 4.57 (br s, 1H, H-30a), 4.69 (br s, 1H, H30-b); ESI-HRMS m/z $487.3418[\mathrm{M}+\mathrm{H}]^{+}$ (calc. for $\mathrm{C}_{30} \mathrm{H}_{47} \mathrm{O}_{5}$ : 487.3423).

\section{3-O-acetyl-dimethyl-ceanothate (1a)}

A mixture of $1(5.1 \mathrm{mg}), \mathrm{K}_{2} \mathrm{CO}_{3}(80 \mathrm{mg}), \mathrm{CH}_{3} \mathrm{I}$ $(300 \mu \mathrm{L})$ and acetone $(1 \mathrm{~mL})$ was stirred for $72 \mathrm{~h}$ at room temperature. The reaction mixture was poured over distilled water $(14 \mathrm{~mL})$ and the resulting suspension was extracted twice with EtOAc $(4: 1, \mathrm{v} / \mathrm{v})$. The organic layer was dried over anhydrous $\mathrm{Na}_{2} \mathrm{SO}_{4}$ and evaporated to produce $4.6 \mathrm{mg}$ of the crude esterified product, which was purified by column chromatography (hexane/ $\mathrm{Me}_{2} \mathrm{CO} 9: 1$ ) to give 1a (4.2 mg, 91.3\% yield) as a white powder. ${ }^{1} \mathrm{H} \mathrm{NMR}\left(\mathrm{CDCl}_{3}\right.$, $600 \mathrm{MHz})$ and ${ }^{13} \mathrm{C} \mathrm{NMR}\left(\mathrm{CDCl}_{3}, 150 \mathrm{MHz}\right)$ data: see Table S1; LR-MS $m / z$. $557[\mathrm{M}+\mathrm{H}]^{+}$.

\section{Dimethyl-ceanothate (2a)}

A fraction containing ceanothic acid as the main product $\left(8.5 \mathrm{mg}\right.$ ), was mixed with $\mathrm{K}_{2} \mathrm{CO}_{3}(220 \mathrm{mg}), \mathrm{CH}_{3} \mathrm{I}$ 
$(800 \mu \mathrm{L})$ and acetone $(1 \mathrm{~mL})$, and then stirred for $72 \mathrm{~h}$ at room temperature. The reaction mixture was poured over distilled water $(13 \mathrm{~mL})$ and the resulting suspension was extracted twice with EtOAc (4:1, v/v). The organic phase was dried over anhydrous $\mathrm{Na}_{2} \mathrm{SO}_{4}$ and evaporated to produce $9.6 \mathrm{mg}$ of the crude esterified product, which was purified by multiple-elution $(5 \times)$ prep-TLC (hexane/ether 7:3) to give $5.4 \mathrm{mg}$ of $\mathbf{4}(56.2 \%)$ as a white solid. ${ }^{1} \mathrm{H}$ NMR $\left(\mathrm{CD}_{3} \mathrm{OD}, 400 \mathrm{MHz}\right)$ and ${ }^{13} \mathrm{C} \mathrm{NMR}\left(\mathrm{CDCl}_{3}, 100 \mathrm{MHz}\right)$ data: see Table S1; ESI-HRMS $m / z 515.3731[\mathrm{M}+\mathrm{H}]^{+}$(calc. for $\mathrm{C}_{32} \mathrm{H}_{51} \mathrm{O}_{5}: 515.3736$ ).

\section{Ceanothenic acid (3)}

White powder; FTIR (film) $v_{\max } / \mathrm{cm}^{-1}: 3067(\mathrm{CH}=\mathrm{C})$, 1721 (carboxyl), 1685 (carboxyl); ${ }^{1} \mathrm{H}$ NMR $\left(\mathrm{CDCl}_{3} /\right.$ $\left.\mathrm{CD}_{3} \mathrm{OD} 9: 1,400 \mathrm{MHz}\right)$ and ${ }^{13} \mathrm{C} \mathrm{NMR}\left(\mathrm{CDCl}_{3} / \mathrm{CD}_{3} \mathrm{OD} 9: 1\right.$, $100 \mathrm{MHz}$ ) data: see Table S1; ESI-HRMS $m / z, 455.3156$ $[\mathrm{M}+\mathrm{H}]^{+}$(calc. for $\mathrm{C}_{29} \mathrm{H}_{43} \mathrm{O}_{4}: 455.3161$ ).

\section{Betulinic acid (4)}

Colorless needles; ESI-HRMS $\mathrm{m} / \mathrm{z} 440.3690$ $\left[\mathrm{M}-\mathrm{H}_{2} \mathrm{O}+2 \mathrm{H}\right]^{+}$(calc. for $\mathrm{C}_{30} \mathrm{H}_{48} \mathrm{O}_{2}: 440.3654$ ).

\section{Discarine B (5)}

White amorphous solid; $v_{\max } / \mathrm{cm}^{-1}: 3267(\mathrm{NH}), 3027$ $(\mathrm{CH}=\mathrm{C}), 1634(>\mathrm{C}=\mathrm{O}) ;{ }^{1} \mathrm{H}$ NMR $\left(\mathrm{CD}_{3} \mathrm{OD}, 30{ }^{\circ} \mathrm{C}\right.$, $400 \mathrm{MHz})$ and ${ }^{13} \mathrm{C} \mathrm{NMR}\left(\mathrm{CD}_{3} \mathrm{OD}, 30^{\circ} \mathrm{C}, 100 \mathrm{MHz}\right)$ data: see Table S3; ESI-HRMS m/z $574.3393[\mathrm{M}+\mathrm{H}]^{+}$(calc. for $\mathrm{C}_{33} \mathrm{H}_{44} \mathrm{~N}_{5} \mathrm{O}_{4}:$ :574.7336).

\section{Chrysophanein (6)}

Yellow powder; FTIR (film) $v_{\text {max }} / \mathrm{cm}^{-1}: 3344(\mathrm{OH}), 1634$ (>C=O); ${ }^{1} \mathrm{H}$ NMR (DMSO- $d_{6}, 400 \mathrm{MHz}$ ) and ${ }^{13} \mathrm{C}$ NMR (DMSO- $d_{6}, 100 \mathrm{MHz}$ ) data: see Table S2; ESI-HRMS $\mathrm{m} / \mathrm{z}$ $255.2302\left[\mathrm{M}-\mathrm{C}_{6} \mathrm{H}_{10} \mathrm{O}_{5}+\mathrm{H}\right]^{+}$(calc. for $\mathrm{C}_{15} \mathrm{H}_{11} \mathrm{O}_{4}: 255.0657$ ).

\section{Chrysophanein peracetate ( $6 \boldsymbol{a}$ )}

A mixture of $6(10 \mathrm{mg})$, acetic anhydride $(1 \mathrm{~mL})$ and pyridine $(0.5 \mathrm{~mL})$ was stirred at room temperature for $72 \mathrm{~h}$. The reaction mixture was poured over distilled water $(20 \mathrm{~mL})$ and the resulting suspension was extracted twice with ethylacetate $(2: 1 \mathrm{v} / \mathrm{v})$. The organic layer was washed successively with equal volumes of $\mathrm{HCl}(5 \%), \mathrm{NaOH}(3 \%)$, $\mathrm{H}_{2} \mathrm{O}$, and $\mathrm{NaCl}$ saturated, and then dried over anhydrous $\mathrm{MgSO}_{4}$. Filtration and evaporation of the solvent yielded $13.9 \mathrm{mg}(92.4 \%)$ of crude acetylated product obtained as a yellow powder; FTIR (film) $v_{\max } \mathrm{cm}^{-1}: 3021(\mathrm{CH}=\mathrm{C})$, 1757 (ester), 1680 (>C=O); ${ }^{1} \mathrm{H}$ NMR $\left(\mathrm{CDCl}_{3}, 400 \mathrm{MHz}\right)$ and ${ }^{13} \mathrm{C}$ NMR $\left(\mathrm{CDCl}_{3}, 100 \mathrm{MHz}\right)$ data: see Table S2; ESIHRMS $m / z 649.1499[\mathrm{M}+\mathrm{Na}]^{+}$(calc. for $\mathrm{C}_{31} \mathrm{H}_{30} \mathrm{NaO}_{14}$ : 649.1533).

\section{Bioassays}

\section{Leishmanicidal assay}

The growth inhibition of promastigotes was carried out following the procedure previously reported by Muñoz et al. ${ }^{39}$ and Inchausti et al. ${ }^{40}$ Briefly, a strain of $L$. amazonensis (IFLA/BR/75/PH8) was grown in Schneider culture medium with $10 \%$ fetal bovine serum (FBS), penicillin $\left(100 \mathrm{IU} \mathrm{mL}^{-1}\right)$ and streptomycin $\left(100 \mathrm{mg} \mathrm{mL}^{-1}\right)$ at $25^{\circ} \mathrm{C}$; parasites in the log phase of their growth cycle were then transferred to a microplate ( 96 wells; $1 \times 10^{5}$ parasites/well). Stock solutions of DMSO (blank), pentamidine (positive control), crude extract, semipurified fractions and pure metabolites were diluted in Schneider medium at $\leq 100 \mu \mathrm{g} \mathrm{mL}^{-1}$, added to the plate, and incubated for $72 \mathrm{~h}$. The percentages of inhibition were obtained by directed observation of each well with an inverted phase microscope. All the assays were carried out in triplicate.

\section{Trypanocidal assay}

Epimastigotes of Trypanosoma cruzi strain Tulahuen parasites were maintained in liver infusion tryptose (LIT) medium supplemented with 5\% FBS, following the procedure modified by Chataing et al. ${ }^{41}$ Briefly, parasites in the log phase of growth cycle were transferred to a microplate (96 wells; $1 \times 10^{6}$ parasites/well) together with stock solutions of benznidazole, DMSO (positive control and blank respectively), extract, semipurified fractions or pure metabolites prepared at different concentrations $\left(\leq 100 \mu \mathrm{g} \mathrm{mL}^{-1}\right)$. The microplates were incubated at $26{ }^{\circ} \mathrm{C}$ for $72 \mathrm{~h}$.

\section{Antiplasmodial assay}

Plasmodium falciparum strain $\mathrm{F} 32$ was grown at $37^{\circ} \mathrm{C}$ in RPMI medium with $10 \%$ of human serum and $4 \%$ of hematocrit $(\mathrm{O}, \mathrm{Rh}+)$, under anaerobic conditions, according to a reported method. ${ }^{41}$ Cultures with $1 \%$ parasitemic and $2 \%$ hematocrite $(100 \mu \mathrm{L})$ were transferred to a 96 well plate. Stock solutions of chloroquine (positive control), DMSO (blank), extract, semipurified fractions or pure metabolites were diluted in RPMI medium to a concentration of $<10 \mu \mathrm{gL}^{-1}$ and added to each well. The plate was then incubated at $37{ }^{\circ} \mathrm{C}$ for $48 \mathrm{~h}$.

\section{Cytotoxicity assay}

Human laryngeal carcinoma (HEp-2), human cervical adenocarcinoma (HeLa), human nasopharyngeal carcinoma (KB), and green monkey Vero kidney cells (VERO) were grown in DMEM (Gibco) media supplemented with $10 \%(\mathrm{v} / \mathrm{v})$ FBS (Gibco), penicillin (100 $\mathrm{IU} \mathrm{mL}^{-1}$ ), and streptomycin $\left(100 \mathrm{mg} \mathrm{mL}^{-1}\right)$. All the cell lines were maintained at $37{ }^{\circ} \mathrm{C}$ in a $5 \% \mathrm{CO}_{2}$ atmosphere with $95 \%$ 
humidity. The cytotoxicity assay was performed according to a method described by Rahman et al..$^{43}$ Briefly, cell lines were transferred to a microplate $\left(1.5 \times 10^{4}\right.$ viable cells of each cell line) and incubated at $37^{\circ} \mathrm{C}$, with $95 \%$ humidity and $5 \% \mathrm{CO}_{2}$ in DMEM medium supplemented with $10 \%$ of FBS, penicillin (10000 IU), streptomycin $\left(10 \mathrm{mg} \mathrm{mL}^{-1}\right)$, and amphotericine B $\left(5 \mathrm{mg} \mathrm{mL}^{-1}\right)$. After $24 \mathrm{~h}$, the medium was replaced by fresh medium with $0.05 \%$ DMSO (blank) or different concentrations of docetaxel (positive control, Sigma), crude extract, semipurified fractions or pure metabolites dissolved in DMSO (100, 50, 25, 12.5 and $6.25 \mu \mathrm{g} \mathrm{mL}^{-1}$ ), and the cells were incubated for $72 \mathrm{~h}$ under the conditions already described. The medium was removed and $200 \mu \mathrm{L}$ of a $0.5 \%$ MTT (Sigma) solution in PBS ( $\mathrm{pH}$ 7.2) were added to each well, and left to stand for $4 \mathrm{~h}$ at $37{ }^{\circ} \mathrm{C}$. Then $100 \mu \mathrm{L}$ of acidified isopropanol $\left(0.4 \mathrm{~mol} \mathrm{~L}^{-1} \mathrm{HCl}\right)$ were added to each well and the optical density (OD) measured at $540 \mathrm{~nm}$ using a Bioassay reader (Bio-Rad). The experiment was carried out in triplicate and each concentration was tested in duplicate.

\section{Antiproliferative assay}

The sulforhodamine B (SRB) assay was carried out according to the method reported by Rahman et al. ${ }^{43}$ using DMEM medium with $10 \%$ FBS to induce cell proliferation. After $48 \mathrm{~h}$ of incubation, the medium was discarded and $100 \mu \mathrm{L}$ of ice-cold $40 \%$ trichloroacetic acid (TCA, Aldrich) were added to fix the cells, incubating for $1 \mathrm{~h}$ at $4{ }^{\circ} \mathrm{C}$. The cells were washed five times with water, left to dry, and then $50 \mu \mathrm{L}$ of SRB stain (10 mg 1\% acetic acid, Sigma) were added to each well and left to stand for $30 \mathrm{~min}$. Finally, the cells were washed with $50 \mathrm{~mL} 1 \%$ acetic acid, and rinsed four times with water. The OD was measured at $540 \mathrm{~nm}$ using an ELISA reader (Bio-Rad model 450). The experiment was carried out in triplicate.

\section{Statistical analysis}

Data were analyzed with commercial software (GraphPad 4.0, Software Inc., San Diego, CA). The doseresponse curves (variable slope) to obtain the inhibitory concentration (in $\mu \mathrm{g} \mathrm{mL}-1$ ) of $50 \%$ of parasites $\left(\mathrm{IC}_{50}\right.$ ), the growth inhibition of $50 \%$ of cells $\left(\mathrm{IG}_{50}\right)$, and the cytotoxic concentration of $50 \%$ of cells $\left(\mathrm{CC}_{50}\right)$, were fitted to the algorithm: $Y=E_{\min }+\left[\left(E_{\max }-E_{\min }\right) /\left(1+10\left(\log \mathrm{ED}_{50}-\right.\right.\right.$ $\log$ D) hill slope)].

\section{Supplementary Information}

Supplementary data (Figures S1-S2, Tables S1-S5) are available free of charge at http://jbcs.sbq.org.br as PDF file.

\section{Acknowledgements}

The authors wish to thank to Paulino Simá for the identification of plant material. This work was supported by Program CYTED (Projects X.5 and RIBIOFAR) and Project FOMIX-Yucatán (66262).

\section{References}

1. World Health Organization; The Global Burden Disease: 2004 update, WHO Library Cataloguing-in-publication data, 2004. http://www.who.int/healthinfo/global_burden_disease/2004_ report_update/en/index.html.

2. Ioset, J. -R.; Curr. Org. Chem. 2008, 12, 643.

3. Fabricant, D. S.; Farnsworth, N. R.; Env. Health Perspect. 2001, 109, 69.

4. Sepúlveda-Boza, S.; Cassels, B. K.; Planta Med. 1996, $62,98$.

5. Chan-Bacab, M. J.; Peña-Rodríguez L. M.; Nat. Prod. Rep. 2001, 18, 674 .

6. Saxena, S.; Pant, N.; Jain, D. C.; Bhakuni, R. S.; Curr. Sci. 2003, 85, 1314.

7. Mendieta, R. M.; Del Almo, S.; Plantas Medicinales del Estado de Yucatán, $1^{\text {st }}$ ed., Compañía Editorial Continental: Xalapa, Mexico, 1981.

8. Vera-Kú, B. M.; Evaluación de la Actividad Biológica en Plantas Medicinales Nativas de la Península de Yucatán, MSc Dissertation, Centro de Investigación Científica de Yucatán: Mérida, Yucatán, México, 2004.

9. Getti, G.; Durgadoss, P.; Dominguez-Carmona, D.; QuintalMartin, Z.; Peraza-Sanchez, S.; Peña-Rodriguez, L. M.; Humber, D.; J. Parasitol. 2009, 95, 456.

10. Johnston, M. C.; Brittonia 1971, 23, 2.

11. Wani, M. C.; Taylor, H. L.; Wall, M. E.; J. Chem. Soc., Chem. Comm. 1973, 390.

12. Wani,M.C.; Taylor,H.L.;Wall,M.E.;TetrahedronLett. 1973,4675.

13. Roitmain, J. N.; Jurd, L.; Phytochemistry 1978, 17, 491.

14. Guinaudeau, H.; Seligmann, O.; Wagner, H.; Neszmely, A.; Phytochemistry 1981, 20, 1113.

15. Baxter, R. L.; Walkinshaw, D.; Phytochemistry 1988, 27, 2350.

16. Oulad-Ali, A.; Guillaume, D.; Weniger, B.; Jiang, Y.; Anton, R.; Phytochemistry 1994, 36, 445.

17. Elsohly, H. N.; Danner, S.; Li, X. C.; Nimrod, A. C.; Clark, A. M.; J. Nat. Prod. 1999, 62, 1341.

18. Xing-Gong, L.; ElSohly, H. N.; Nimrod, A. C.; Clark, M. A.; J. Nat. Prod. 1999, 62, 674.

19. García-Sosa, K.; Villarreal-Alvarez, N.; Lübben, P.; PeñaRodríguez, L. M.; J. Mex. Chem. Soc. 2006, 50, 76.

20. Julian, P. L.; Pikl, J.; Dawson, R.; J. Am. Chem. Soc. 1938, 60, 77.

21. Herz, W.; Falk, H.; Kirby, G. W.; Moore, R. E.; Tamm, C; Progress in the Chemistry of Organic Natural Products, Springer-Verlag Wien: Ney York, 1998. 
22. Kubo, I.; Murai, Y.; Soediro, I.; Soetarno, S.; Sastrodihardjo, S.; Phytochemistry 1992, 31, 1063.

23. De Mayo, P.; Starratt, A. N.; Can. J. Chem. 1962, 49, 1632.

24. Mahato, S. B.; Kundu, A. P.; Phytochemistry 1994, 37, 1517.

25. Duker-Eshun, G.; Jaroszewski, J.W.; Asomaning, W.A.; Phytother. Res. 2004, 18, 128.

26. Ziegler, H. L.; Franzyk, H.; Sairafianpour, M.; Tabatabai, M.; Tehrani, M. D.; Bagherzadeh, K.; Hägerstrand, H.; Stærk, D.; Jaroszewski, J. W.; Bioorg. Med. Chem. 2004, 12, 119.

27. Suksamrarn, S.; Panseeta, P.; Kunchanawatta, S.; Distaporn, T.; Ruktasing, S.; Suksamrarn, A.; Chem. Pharm. Bull. 2006, 54, 535.

28. Popoca, J.; Aguilar, A.; Alonso, D.; Villarreal, M. L.; J. Ethnopharmacol. 1998, 59, 173.

29. Lee, S. -S.; Su, W. -C.; Liu, K. C.; J. Nat. Prod. 1991, 54, 615

30. Li, X. C.; Cai, L.; Wu, C. D.; Phytochemistry 1997, 46, 97.

31. Lee, S. -S.; Chen, W. -C; Huang, C. -F.; Su, Y.; J. Nat. Prod. 1998, 61, 1343.

32. Popoca, J.; Aguilar, A.; Alonso, D.; Villarreal, M. L.; J. Ethnopharmacol. 1998, 59, 173.

33. Eade, R. A.; Ellis, J.; Harper, P.; Simes, J. J. H.; Aust. J. Chem. 1973, 26, 831.

34. Lee, S. -S.; Lin, B. F.; Liu, K. C. S.; Phytochemistry 1996, $43,847$.
35. Lee, S. -S.; Shy, S. N.; Liu, K. C. S.; Phytochemistry 1997, 46, 549.

36. Lee, S. M.; Min, B. S.; Lee, C. G.; Kim, K. S.; Kho, Y. H.; Planta Med. 2003, 69, 1051.

37. Giacomelli, S. R.; Maldener, G.; Stücker, C.; Marasclulo, C.; Schmidt, J.; Wessjohann, L.; Dalcol, I. I.; Morel, A. F.; Planta Med. 2007, 73, 488.

38. Richardson, J. E.; Fay, M. F.; Cronk, Q. C. B.; Bowman, D.; Chase, M. W.; Am. J. Bot. 2000, 87, 1309.

39. Muñoz, V.; Moretti, C.; Sauvain, M.; Caron, C.; Porzel, A.; Massiot, G.; Richard, B.; Le Men-Olivier, L.; Planta Med. 1994, 60, 455 .

40. Inchausti, A.; Yaluff, G.; Arias, A. R.; Torres, S.; Ferreira, M. E.; Nakayama, H.; Schinini, A.; Lorenzen, K.; Anke, T.; Fournet, A.; Phytother. Res. 1997, 11, 193.

41. Chataing, B.; Concepción, J. L.; Lobaton, R.; Usubillaga, A.; Planta Med. 1998, 64, 31.

42. Trager, W.; Jensen, J. B.; Science 1976, 193, 673.

43. Rahman, A.; Choudhary, M. I.; Thomsen, W. J.; Manual of Bioassay Techniques for Natural Products Research, Harwood Academic Publishers: Netherlands, 2001.

Submitted: December 14, 2010

Published online: March 11, 2011 


\title{
Metabolites from Roots of Colubrina greggii var. yucatanensis and Evaluation of their Antiprotozoan, Cytotoxic and Antiproliferative Activities
}

\author{
Dafne B. Domínguez-Carmona, ${ }^{a}$ Fabiola Escalante-Erosa,${ }^{a}$ Karlina García-Sosa, ${ }^{a}$
} Grace Ruiz-Pinell, ${ }^{b}$ David Gutierrez-Yapu, ${ }^{b}$ Manuel J. Chan-Bacab, ${ }^{c}$ Rosa E. Moo-Puc, ${ }^{d}$ Nigel C. Veitch, ${ }^{e}$ Alberto Giménez-Turba ${ }^{b}$ and Luis M. Peña-Rodríguez, ${ }^{* a}$

${ }^{a}$ Unidad de Biotecnología, Centro de Investigación Científica de Yucatán. Calle 43, N. 130, Col. Chuburná, Mérida, Yucatán, 97200 México

${ }^{b}$ Instituto de Investigaciones Fármaco-Bioquímicas, Universidad Mayor de San Andrés, Av. Saavedra 2224, La Paz, Bolivia

'Departamento de Microbiología Ambiental y Biotecnología, Universidad Autónoma de Campeche, Agustín Melgar s/n, Campeche, Campeche, México

${ }^{d}$ Unidad de Investigación Médica Yucatán, Unidad Médica de Alta Especialidad, Centro Médico Ignacio García Téllez IMSS, Calle 41, N. 439, Col. Industrial, Mérida, Yucatán, 97150 México

e Jodrell Laboratory, Royal Botanic Gardens Kew, Richmond, Surrey, TW9 3AB UK

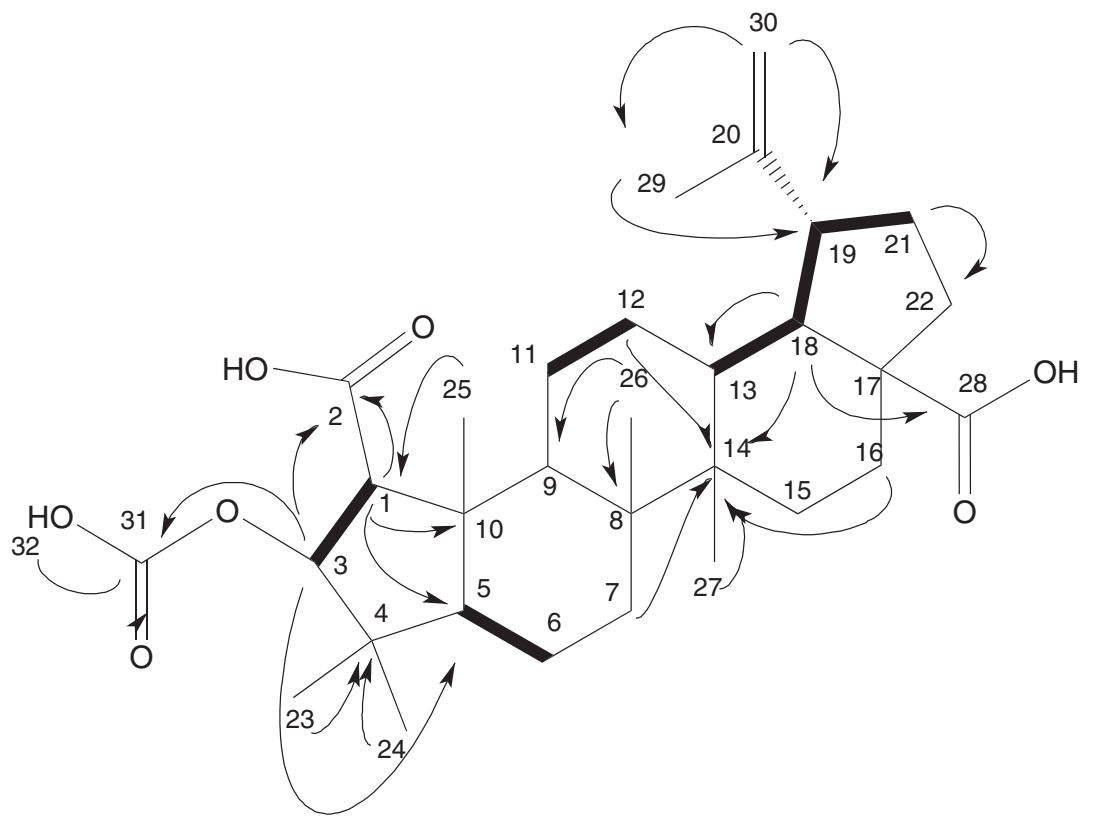

Figure S1. Principal ${ }^{1} \mathrm{H}-{ }^{1} \mathrm{H}$ COSY couplings $(-)$ and $\mathrm{HMBC}(\mathrm{H} \rightarrow \mathrm{C})$ correlations in 3-O-acetyl-ceanothic acid (1). 

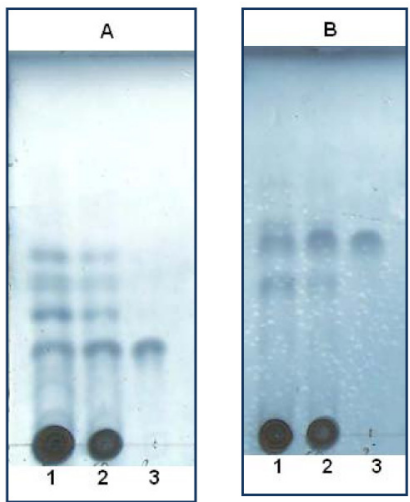

Figure S2. TLC analyses of 3-O-acetyl ceanothic acid (1) in the crude extract of root from $C$. greggii. 1) crude extract of root from $C$. greggii; 2) Co-chromatography of crude extract and 3-O-acetyl ceanothic acid (1); 3) 3-O-acetyl ceanothic acid (1); (A) hexane/Me $\mathrm{M}_{2} \mathrm{CO} 8: 2$; (B) ether/hexane 1:1.

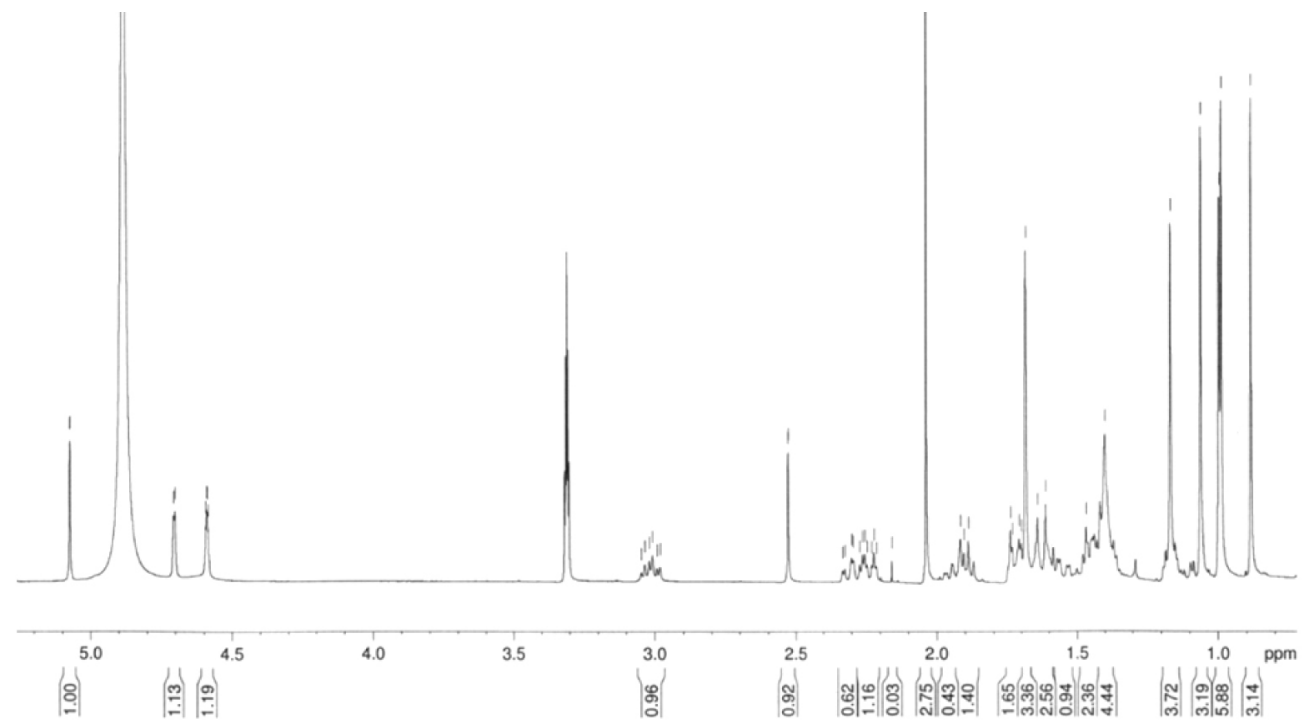

Figure S3. ${ }^{1} \mathrm{H}$ NMR spectrum of $\mathbf{1}\left(\mathrm{CD}_{3} \mathrm{OD}, 400 \mathrm{MHz}\right)$.

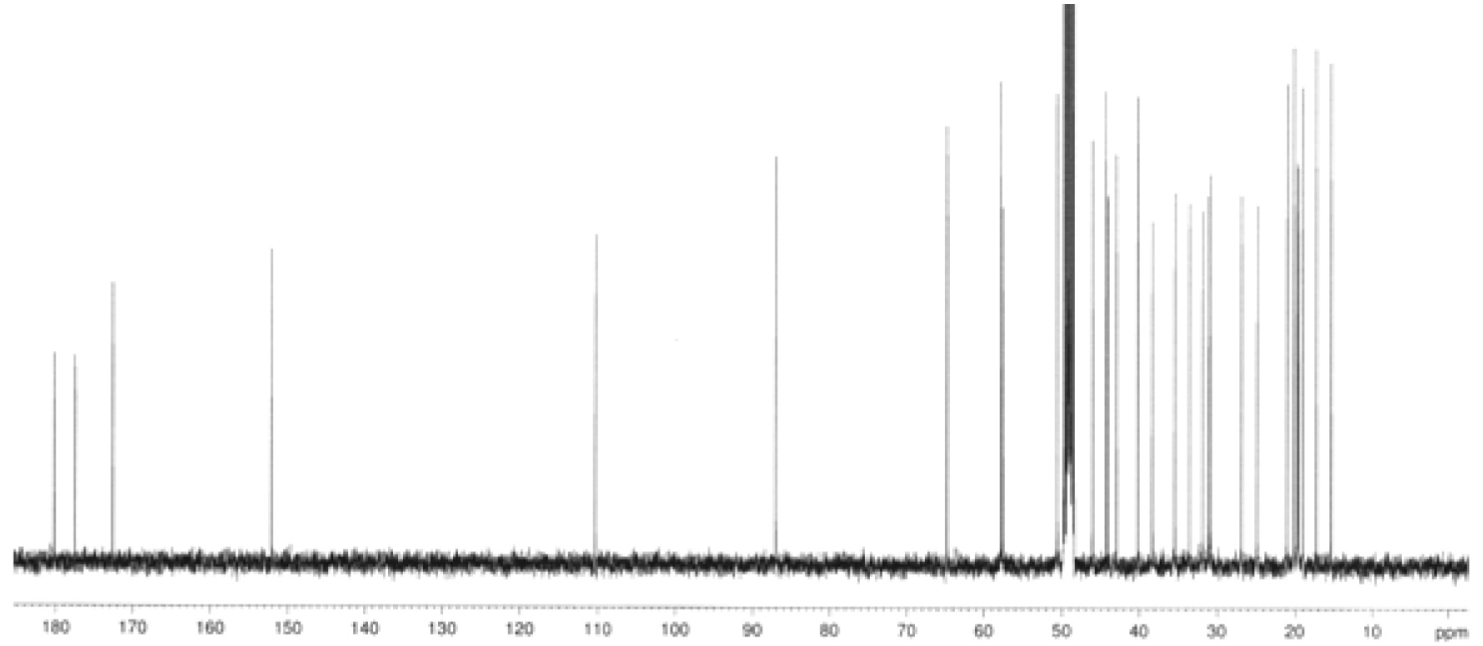

Figure S4. ${ }^{13} \mathrm{C}$ NMR spectrum of $\mathbf{1}\left(\mathrm{CD}_{3} \mathrm{OD}, 100 \mathrm{MHz}\right)$. 
Table S1. ${ }^{13} \mathrm{C}$ and ${ }^{1} \mathrm{H}$ NMR data $(\delta$ in ppm) for 3-O-acetyl ceanothic acid (1), dimethyl ceanothate (2a), ceanothenic acid (3) (400 MHz and $100 \mathrm{MHz}$, respectively) and acetyl-dimethyl ceanothate (1a) $(600 \mathrm{MHz}$ and $150 \mathrm{MHz}$, respectively)

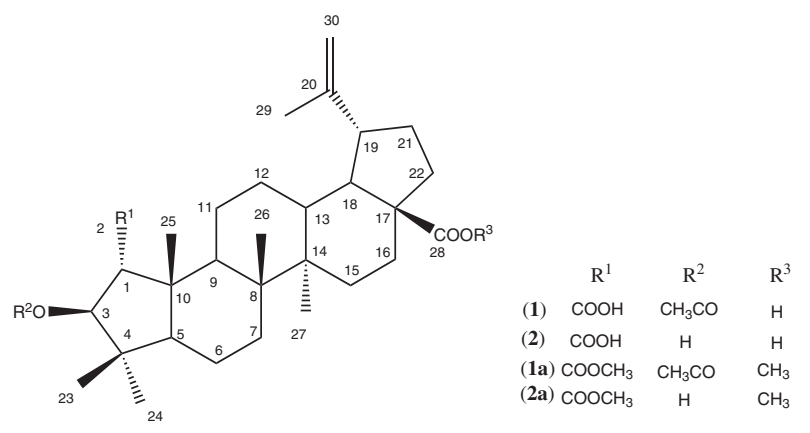

\begin{tabular}{|c|c|c|c|c|c|c|c|c|c|}
\hline \multirow{2}{*}{$\mathrm{C} / \mathrm{H}$} & \multicolumn{3}{|c|}{1} & \multicolumn{2}{|c|}{$1 \mathbf{a}$} & \multicolumn{2}{|c|}{$2 \mathbf{a}$} & \multicolumn{2}{|c|}{3} \\
\hline & $\delta_{\mathrm{C}}($ mult $)$ & $\delta_{\mathrm{H}}(J \mathrm{~Hz})$ & HMBC & $\delta_{\mathrm{C}}($ mult $)$ & $\delta_{\mathrm{H}}(J \mathrm{~Hz})$ & $\delta_{\mathrm{C}}($ mult $)$ & $\delta_{\mathrm{H}}(J \mathrm{~Hz})$ & $\delta_{\mathrm{C}}$ (mult) & $\delta_{\mathrm{H}}(J \mathrm{~Hz})$ \\
\hline 1 & $64.7(d)$ & $2.52 \mathrm{~d}(0.8)$ & $\begin{array}{l}\text { C-2, C-3, } \\
\text { C-5, C-10 }\end{array}$ & $62.9(d)$ & $2.59 \mathrm{~s}$ & $65.5(d)$ & $2.50 \mathrm{~s}$ & $140.1(\mathrm{~d})$ & $5.55 \mathrm{~d}(5.7)$ \\
\hline 2 & $177.4(\mathrm{~s})$ & & & $174.2(\mathrm{~s})$ & & $175.9(\mathrm{~s})$ & & - & - \\
\hline 3 & $87.0(\mathrm{~d})$ & $5.07 \mathrm{~d}(0.8)$ & C-2, C-31 & $85.1(\mathrm{~d})$ & $5.09 \mathrm{~s}$ & 84.9 (d) & $4.07 \mathrm{~s}$ & $138.2(\mathrm{~d})$ & $5.01 \mathrm{~d}(5.0)$ \\
\hline 4 & $44.0(\mathrm{~s})$ & & & $42.9(\mathrm{~s})$ & & $43.4(\mathrm{~s})$ & & $44.0(\mathrm{~s})$ & \\
\hline 5 & $57.8(d)$ & $1.71 \mathrm{~m}$ & C- 10 & $56.2(\mathrm{~d})$ & $1.66 \mathrm{~m}$ & $56.6(d)$ & $1.53 \mathrm{~m}$ & $61.9(\mathrm{~d})$ & $0.86 \mathrm{~m}$ \\
\hline 6 & $19.5(\mathrm{t})$ & $1.43 \mathrm{~m}$ & & $18.2(\mathrm{t})$ & $\begin{array}{l}1.33 \mathrm{~m} \\
1.40 \mathrm{~m}\end{array}$ & $18.6(t)$ & $1.27 \mathrm{~m}$ & $16.8(t)$ & $1.07 \mathrm{~m}$ \\
\hline 7 & $35.4(\mathrm{t})$ & $\begin{array}{l}1.40 \mathrm{~m} \\
1.97 \mathrm{~m}\end{array}$ & C-14 & $33.8(\mathrm{t})$ & $\begin{array}{l}1.33 \mathrm{~m} \\
1.40 \mathrm{~m}\end{array}$ & $34.0(\mathrm{t})$ & $1.27 \mathrm{~m}$ & $36.9(\mathrm{t})$ & $\begin{array}{l}1.25 \mathrm{~m} \\
1.33 \mathrm{~m}\end{array}$ \\
\hline 8 & $42.9(\mathrm{~s})$ & & & $41.5(\mathrm{~s})$ & & $42.9(\mathrm{~s})$ & & $40.7 \mathrm{qC}$ & \\
\hline 9 & $46.1(\mathrm{~d})$ & $1.71 \mathrm{~m}$ & & 44.6 (d) & $1.46 \mathrm{~m}$ & 44.7 (d) & $1.36 \mathrm{~m}$ & 47.4 (d) & $\begin{array}{c}1.48 \mathrm{dd} \\
(3.2,12.3)\end{array}$ \\
\hline 10 & $50.6(\mathrm{~s})$ & & & $49.4(\mathrm{~s})$ & & $49.5(\mathrm{~s})$ & & $50.0(\mathrm{~s})$ & \\
\hline 11 & $24.8(\mathrm{t})$ & $\begin{array}{l}1.43 \mathrm{~m} \\
1.62 \mathrm{~m}\end{array}$ & C-10 & $23.4(t)$ & $1.46 \mathrm{~m}$ & $23.6(t)$ & $1.36 \mathrm{~m}$ & $22.3(\mathrm{t})$ & $1.20 \mathrm{~m}$ \\
\hline 12 & $26.8(\mathrm{t})$ & $\begin{array}{l}1.11 \mathrm{~m} \\
1.62 \mathrm{~m}\end{array}$ & C-14 & $25.2(\mathrm{t})$ & $\begin{array}{l}0.95 \mathrm{~m} \\
1.60 \mathrm{~m}\end{array}$ & $25.5(\mathrm{t})$ & $\begin{array}{l}0.82 \mathrm{~m} \\
1.83 \mathrm{~m}\end{array}$ & $25.2(\mathrm{t})$ & $\begin{array}{l}1.30 \mathrm{~m} \\
1.74 \mathrm{~m}\end{array}$ \\
\hline 13 & $40.1(\mathrm{~d})$ & $2.27 \mathrm{~m}$ & & $38.4(d)$ & $\begin{array}{c}2.18 \mathrm{td} \\
(11.0,7.5)\end{array}$ & 38.7 (d) & $2.08 \mathrm{~m}$ & 39.0 (d) & $2.02 \mathrm{~m}$ \\
\hline 14 & $44.3(\mathrm{~s})$ & & & $42.7(\mathrm{~s})$ & & $41.7(\mathrm{~s})$ & & $59.3(\mathrm{~s})$ & \\
\hline 15 & $31.8(\mathrm{t})$ & $\begin{array}{l}1.43 \mathrm{~m} \\
1.90 \mathrm{~m}\end{array}$ & & $30.5(\mathrm{t})$ & $\begin{array}{l}1.36 \mathrm{~m} \\
1.87 \mathrm{~m}\end{array}$ & $30.9(\mathrm{t})$ & $\begin{array}{l}1.27 \mathrm{~m} \\
1.80 \mathrm{~m}\end{array}$ & $27.4(\mathrm{t})$ & $\begin{array}{l}1.00 \mathrm{~m} \\
1.74 \mathrm{~m}\end{array}$ \\
\hline 16 & $33.5(\mathrm{t})$ & $\begin{array}{l}1.43 \mathrm{~m} \\
2.27 \mathrm{~m}\end{array}$ & C-14 & $29.7(t)$ & $\begin{array}{l}1.13 \mathrm{~m} \\
1.36 \mathrm{~m}\end{array}$ & $32.3(\mathrm{t})$ & $\begin{array}{l}1.78 \mathrm{~m} \\
2.11 \mathrm{~m}\end{array}$ & $33.7(t)$ & $\begin{array}{l}0.95 \mathrm{~m} \\
1.99 \mathrm{~m}\end{array}$ \\
\hline 17 & $57.5(\mathrm{~s})$ & & & $56.4(\mathrm{~s})$ & & $56.7(\mathrm{~s})$ & & $55.6(\mathrm{~s})$ & \\
\hline 18 & $50.5(\mathrm{~d})$ & $1.62 \mathrm{~m}$ & $\begin{array}{c}\text { C-13,C-14, } \\
\text { C-17, C-19, } \\
\text { C-28 }\end{array}$ & 49.2 (d) & $1.54 \mathrm{t}(11.4)$ & $49.6(d)$ & $1.45 \mathrm{t}(11.4)$ & $50.9(\mathrm{~d})$ & $1.36 \mathrm{~m}$ \\
\hline 19 & $48.6(d)$ & $\begin{array}{c}3.01 \mathrm{dt} \\
(10.8,4.5)\end{array}$ & C-29 & $46.8(d)$ & $\begin{array}{c}2.97 \mathrm{dt} \\
(10.5,4.7)\end{array}$ & $47.0(\mathrm{~d})$ & $\begin{array}{c}2.88 \mathrm{dt} \\
(10.9,4.6)\end{array}$ & $46.6(d)$ & $\begin{array}{c}2.72 \mathrm{dt} \\
(7.5,4.0)\end{array}$ \\
\hline 20 & $152.0(\mathrm{~s})$ & & & $150.3(\mathrm{~s})$ & & $150.5(\mathrm{~s})$ & & $149.7(\mathrm{~s})$ & \\
\hline 21 & $31.1(\mathrm{t})$ & $1.62 \mathrm{~m}$ & $\mathrm{C}-22$ & $32.1(\mathrm{t})$ & $2.23 \mathrm{~m}$ & $30.7(t)$ & $\begin{array}{l}1.27 \mathrm{~m} \\
180 \mathrm{~m}\end{array}$ & $29.8(t)$ & $\begin{array}{l}1.00 \mathrm{~m} \\
1.57 \mathrm{~m}\end{array}$ \\
\hline 22 & $38.3(t)$ & $\begin{array}{l}1.43 \mathrm{~m} \\
1.90 \mathrm{~m}\end{array}$ & & $36.9(\mathrm{t})$ & $\begin{array}{l}1.36 \mathrm{~m} \\
1.87 \mathrm{~m}\end{array}$ & $37.0(\mathrm{t})$ & $\begin{array}{l}1.27 \mathrm{~m} \\
1.78 \mathrm{~m}\end{array}$ & $36.5(\mathrm{t})$ & $\begin{array}{l}1.00 \mathrm{~m} \\
1.56 \mathrm{~m}\end{array}$ \\
\hline 23 & $30.8(q)$ & $1.16 \mathrm{~s}$ & $\begin{array}{l}\text { C-3, C-4, } \\
\text { C-5, C-24 }\end{array}$ & $30.2(q)$ & $1.19 \mathrm{~s}$ & $29.8(q)$ & $1.16 \mathrm{~s}$ & $28.6(q)$ & $0.59 \mathrm{~s}$ \\
\hline 24 & $20.1(q)$ & $0.88 \mathrm{~s}$ & $\begin{array}{l}\text { C-3, C-4, } \\
\text { C-5, C-23 }\end{array}$ & $19.5(q)$ & $0.85 \mathrm{~s}$ & $29.9(q)$ & $1.03 \mathrm{~s}$ & $20.5(q)$ & $0.53 \mathrm{~s}$ \\
\hline 25 & $18.9(q)$ & $1.06 \mathrm{~s}$ & $\begin{array}{l}\text { C-1, C-5, } \\
\text { C-9, C-10 }\end{array}$ & $18.0(q)$ & $1.02 \mathrm{~s}$ & $14.8(q)$ & $0.82 \mathrm{~s}$ & $19.3(q)$ & $0.60 \mathrm{~s}$ \\
\hline 26 & $17.2(q)$ & $0.98 \mathrm{~s}$ & $\mathrm{C}-7, \mathrm{C}-9$ & $16.4(q)$ & $0.92 \mathrm{~s}$ & $18.5(q)$ & $0.97 \mathrm{~s}$ & $17.2(q)$ & $0.68 \mathrm{~s}$ \\
\hline 27 & $15.3(\mathrm{q})$ & $0.99 \mathrm{~s}$ & $\begin{array}{l}\text { C-8, C-13, } \\
\text { C- } 14, \text { C-15 }\end{array}$ & $14.6(q)$ & $0.91 \mathrm{~s}$ & $16.6(q)$ & $0.83 \mathrm{~s}$ & $178.5(\mathrm{~s})$ & \\
\hline 28 & $180.1(\mathrm{~s})$ & & & $176.6(\mathrm{~s})$ & & $176.8(\mathrm{~s})$ & & $177.8(\mathrm{~s})$ & \\
\hline 29 & $19.7(q)$ & $1.68 \mathrm{~s}$ & C-19 & $19.4(q)$ & $1.67 \mathrm{~s}$ & $19.3(\mathrm{q})$ & $1.57 \mathrm{~s}$ & $17.9(\mathrm{q})$ & $1.32 \mathrm{~s}$ \\
\hline 30 & $110.3(\mathrm{t})$ & $\begin{array}{c}4.58 \mathrm{dd} \\
(2.2,1.4)\end{array}$ & C-19, C-29 & $109.6(\mathrm{t})$ & $4.60 \mathrm{sa}$ & $109.7(\mathrm{t})$ & $4.50 \mathrm{sa}$ & $109.1(\mathrm{t})$ & $4.22 \mathrm{~d}(2.2)$ \\
\hline & & $4.70 \mathrm{~d}(2.0)$ & & & $4.72 \mathrm{sa}$ & & $4.63 \mathrm{sa}$ & & $4.35 \mathrm{~d}(2.1)$ \\
\hline $\mathrm{C}=\mathrm{O}$ & $172.5(\mathrm{~s})$ & & & $170.5(\mathrm{~s})$ & & & & & \\
\hline $\mathrm{Me}$ & $21.0(q)$ & $2.03 \mathrm{~s}$ & $\mathrm{C}-31$ & $21.0(\mathrm{q})$ & $2.04 \mathrm{~s}$ & & & & \\
\hline $\mathrm{MeO}$ & & & & $51.5(\mathrm{q})$ & $3.68 \mathrm{~s}$ & $51.4(q)$ & $3.50 \mathrm{~s}$ & & \\
\hline $\mathrm{MeO}$ & & & & $51.3(\mathrm{q})$ & $3.66 \mathrm{~s}$ & $51.4(\mathrm{q})$ & $3.50 \mathrm{~s}$ & & \\
\hline
\end{tabular}


Table S2. ${ }^{13} \mathrm{C}$ and ${ }^{1} \mathrm{H}$ NMR data for compounds 6 and $6 \mathbf{6}$

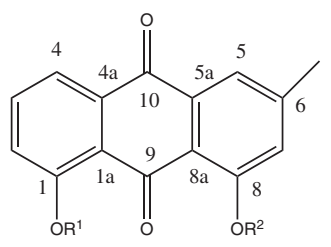

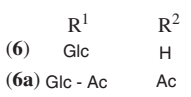

\begin{tabular}{|c|c|c|c|c|c|c|c|c|}
\hline \multirow{2}{*}{$\mathrm{C} / \mathrm{H}$} & \multicolumn{3}{|c|}{6} & \multicolumn{5}{|c|}{$6 a$} \\
\hline & $\delta_{\mathrm{C}}$ (mult) & $\delta_{\mathrm{H}}(J \mathrm{~Hz})$ & $\delta_{\mathrm{C}}$ (mult) & $\delta_{\mathrm{H}}(J \mathrm{~Hz})$ & $\mathrm{Me}$ & $\delta_{\mathrm{C}}$ & $\mathrm{C}=\mathrm{O}$ & $\delta_{\mathrm{C}}$ \\
\hline 1 & $147.5(\mathrm{~s})$ & & $149.6(\mathrm{~s})$ & & $6 "$ & $21.0(\mathrm{q})$ & $6 "$, & $170.4(\mathrm{~s})$ \\
\hline $1 \mathrm{a}$ & $114.7(\mathrm{~s})$ & & $123.9(\mathrm{~s})$ & & & & & \\
\hline 2 & $124.0(\mathrm{~d})$ & $7.17 \mathrm{dd}(1.6,0.7)$ & $130.6(d)$ & $7.20 \mathrm{dd}(1.8,0.6)$ & & & & \\
\hline 3 & $118.2(\mathrm{~s})$ & & $145.5(\mathrm{~s})$ & & & & & \\
\hline 4 & 119.3 (d) & $7.47 \mathrm{dd}(1.6,0.7)$ & $125.5(\mathrm{~d})$ & $7.97 \mathrm{dd}(1.8,0.6)$ & & & & \\
\hline $4 \mathrm{a}$ & $132.1(\mathrm{~s})$ & & $134.2(\mathrm{~s})$ & & & & & \\
\hline 5 & $120.5(\mathrm{~d})$ & $7.85 \mathrm{~m}$ & $122.1(\mathrm{~d})$ & $8.00 \mathrm{dd}(7.5,1.2)$ & & & & \\
\hline $5 \mathrm{a}$ & $136.1(\mathrm{~s})$ & & $134.8(\mathrm{~s})$ & & & & & \\
\hline 6 & $135.8(\mathrm{~d})$ & $7.85 \mathrm{~m}$ & $134.3(\mathrm{~d})$ & $7.65 \mathrm{dd}(7.6,7.6)$ & & & & \\
\hline 7 & $122.4(\mathrm{~d})$ & $7.70 \mathrm{dd}(2.8,1.3)$ & $123.3(\mathrm{~d})$ & $7.45 \mathrm{dd}(8.4,1.2)$ & & & & \\
\hline 8 & $158.1(\mathrm{~s})$ & & $156.4(\mathrm{~s})$ & & & & & \\
\hline $8 a$ & $121.2(\mathrm{~s})$ & & $123.8(\mathrm{~s})$ & & & & & \\
\hline 9 & $187.4(\mathrm{~s})$ & & $180.5(\mathrm{~s})$ & & & & & \\
\hline 10 & $182.0(\mathrm{~s})$ & & $182.7(\mathrm{~s})$ & & & & & \\
\hline 1 ' & $100.5(d)$ & $5.08 \mathrm{~d}(5.1)$ & $99.8(\mathrm{~d})$ & $5.13 \mathrm{~d}(7.8)$ & & & & \\
\hline 2 ' & $77.2(\mathrm{~d})$ & $3.46 \mathrm{~m}$ & $70.4(\mathrm{~d})$ & $5.50 \mathrm{dd}(9.3,7.8)$ & $2 "$ & $20.5(q)$ & $2, "$ & $169.6(\mathrm{~s})$ \\
\hline 3 ' & $73.2(\mathrm{~d})$ & $3.46 \mathrm{~m}$ & $72.6(d)$ & $5.31 \mathrm{dd}(9.6,9.6)$ & $3 "$ & $20.6(q)$ & $3^{\prime \prime \prime}$ & $170.2(\mathrm{~s})$ \\
\hline $4^{\prime}$ & $69.5(\mathrm{~d})$ & $3.21 \mathrm{~m}$ & $68.2(\mathrm{~d})$ & $5.22 \mathrm{dd}(9.5,9.5)$ & $4 "$ & $20.6(q)$ & $4 "$, & $169.3(\mathrm{~s})$ \\
\hline 5, & $76.5(\mathrm{~d})$ & $3.31 \mathrm{~m}$ & $72.2(\mathrm{~d})$ & 3.90 ddd $(12.3,9.5,2.6)$ & $5 "$ & $20.8(q)$ & $5 "$, & $170.1(\mathrm{~s})$ \\
\hline 6 & $60.6(t)$ & $\begin{array}{c}3.46 \mathrm{~m} \\
3.70 \mathrm{dd}(10.0,5.5)\end{array}$ & $61.8(\mathrm{t})$ & $\begin{array}{l}4.20 \text { ddd }(12.3,9.5,2.6) \\
4.28 \text { ddd }(12.3,9.5,2.6)\end{array}$ & & & & \\
\hline 11 & $21.4(q)$ & $2.41 \mathrm{~s}$ & $21.6(q)$ & $2.49 \mathrm{~s}$ & & & & \\
\hline
\end{tabular}


Table S3. ${ }^{13} \mathrm{C}$ and ${ }^{1} \mathrm{H}$ NMR data for compound 5 in $\mathrm{CD}_{3} \mathrm{OD}$ at $30{ }^{\circ} \mathrm{C}(400 \mathrm{MHz})$

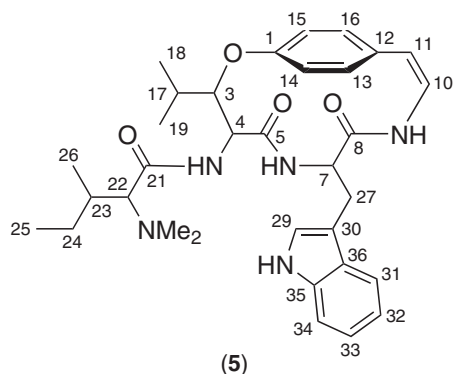

(5)

5

\begin{tabular}{|c|c|c|c|}
\hline \multirow{2}{*}{$\mathrm{C} / \mathrm{H}$} & \multicolumn{3}{|c|}{5} \\
\hline & $\delta \mathrm{c}$ (mult.) & $\delta_{\mathrm{H}}(J \mathrm{~Hz})$ & HMBC \\
\hline 1 & $157.7(\mathrm{~s})$ & & \\
\hline 3 & $82.0(\mathrm{~d})$ & $4.86 \mathrm{dd}(8.4,1.7)$ & $\mathrm{C}-1, \mathrm{C}-4, \mathrm{C}-5, \mathrm{C}-17, \mathrm{C}-18, \mathrm{C}-19$ \\
\hline 4 & $56.8(\mathrm{~d})$ & $4.48 \mathrm{~d}(8.4)$ & $\mathrm{C}-3, \mathrm{C}-5, \mathrm{C}-17, \mathrm{C}-21$ \\
\hline 5 & $172.4(\mathrm{~s})$ & & \\
\hline 7 & $55.5(\mathrm{~d})$ & $4.26 \mathrm{dd}(9.1,5.0)$ & $\mathrm{C}-8, \mathrm{C}-27, \mathrm{C}-30$ \\
\hline 8 & $172.1(\mathrm{~s})$ & & \\
\hline 10 & $127.0(\mathrm{~d})$ & $5.97 \mathrm{br} \mathrm{s}$ & \\
\hline 11 & $131.0(\mathrm{~d})$ & $6.67 \mathrm{br} \mathrm{s}$ & \\
\hline 12 & $132.4(\mathrm{~s})$ & & \\
\hline $13 / 16^{\mathrm{a}}$ & $\begin{array}{l}131.4(d) \\
130.4(d)\end{array}$ & $\begin{array}{l}6.90 \mathrm{~m} \\
6.96 \mathrm{~m}\end{array}$ & $\begin{array}{l}\mathrm{C}-1 \\
\mathrm{C}-1\end{array}$ \\
\hline $14 / 15^{\mathrm{a}}$ & $\begin{array}{l}122.2(d) \\
119.2(d)\end{array}$ & $\begin{array}{l}6.96 \mathrm{~m} \\
6.97 \mathrm{~m}\end{array}$ & $\begin{array}{l}\mathrm{C}-12 \\
\mathrm{C}-12\end{array}$ \\
\hline 17 & $30.0(\mathrm{~d})$ & $2.19 \mathrm{~m}$ & C- $18, C-19$ \\
\hline $18 / 19^{\mathrm{a}}$ & $\begin{array}{l}20.8(\mathrm{q}) \\
15.4(\mathrm{q})\end{array}$ & $\begin{array}{l}1.19 \mathrm{~d}(6.9) \\
1.01 \mathrm{~d}(6.8)\end{array}$ & $\begin{array}{l}\text { C-3, C-17, C-18/19 } \\
\text { C-3, C-17, C-18/19 }\end{array}$ \\
\hline 21 & $173.2(\mathrm{~s})$ & & \\
\hline 22 & 74.4 (d) & $2.64 \mathrm{~d}(8.4)$ & $\mathrm{C}-21, \mathrm{C}-23, \mathrm{C}-24, \mathrm{C}-26, \mathrm{NMe}_{2}$ \\
\hline 23 & $35.6(d)$ & $1.81 \mathrm{~m}$ & C-21, C-22, C-24, C-26 \\
\hline 24 & $27.1(\mathrm{t})$ & $\begin{array}{l}1.59 \mathrm{~m} \\
1.09 \mathrm{~m}\end{array}$ & $\begin{array}{l}\text { C-22, C-23, C-25, C-26 } \\
\text { C-22, C-23, C-25, C-26 }\end{array}$ \\
\hline 25 & $11.4(\mathrm{q})$ & $0.87 \mathrm{t}(7.4)$ & $\mathrm{C}-23, \mathrm{C}-24$ \\
\hline 26 & $15.6(q)$ & $0.74 \mathrm{~d}(6.7)$ & C-22, C-23, C-24 \\
\hline $\mathrm{NMe}_{2}$ & $42.5(\mathrm{q})$ & $2.24 \mathrm{~s}$ & $\mathrm{C}-21, \mathrm{C}-22$ \\
\hline 27 & $29.6(t)$ & $\begin{array}{l}2.99 \text { br dd (14.0) } \\
2.74 \text { br dd (14.0) }\end{array}$ & \\
\hline 29 & $124.7(d)$ & $6.99 \mathrm{~s}$ & $\mathrm{C}-7, \mathrm{C}-27, \mathrm{C}-30, \mathrm{C}-35, \mathrm{C}-36$ \\
\hline 30 & $110.4(\mathrm{~s})$ & & \\
\hline 31 & $119.3(\mathrm{~d})$ & 7.44 br d (7.9) & $\mathrm{C}-30, \mathrm{C}-33, \mathrm{C}-35, \mathrm{C}-36$ \\
\hline 32 & $119.8(d)$ & 6.96 ddd $(8.0,7.0,1.1)$ & C-31, C-34, C-36 \\
\hline 33 & $122.5(\mathrm{~d})$ & 7.06 ddd $(8.2,7.0,1.2)$ & C-31, C-34, C-35 \\
\hline 34 & $112.3(\mathrm{~d})$ & $7.29 \mathrm{dt}(8.1,0.8)$ & $\mathrm{C}-32, \mathrm{C}-36$ \\
\hline 35 & $138.1(\mathrm{~s})$ & & \\
\hline 36 & $128.6(\mathrm{~s})$ & & \\
\hline
\end{tabular}

${ }^{\mathrm{a} A s s i g n m e n t s ~ i n t e r c h a n g e a b l e . ~}$ 
Table S4. Cytotoxic activity $\left[\mathrm{CC}_{50}\left(\mu \mathrm{g} \mathrm{mL} \mathrm{m}^{-1}\right)\right]$ in HeLa, $\mathrm{KB}, \mathrm{HEp}-2$ and VERO cells of organic crude extract from C. greggii, low and medium polarity fractions, compounds 1-6, and semisynthetic derivatives 1a, 2a and 6a

\begin{tabular}{|c|c|c|c|c|c|c|c|}
\hline \multirow{3}{*}{$\begin{array}{l}\text { Extract/ fraction/ } \\
\text { compund }\end{array}$} & \multicolumn{7}{|c|}{ Cytotoxic activity } \\
\hline & \multicolumn{2}{|c|}{$\mathrm{HeLa}$} & \multicolumn{2}{|c|}{$\mathrm{KB}$} & \multicolumn{2}{|c|}{ HEp-2 } & \multirow{2}{*}{$\begin{array}{l}\text { VERO } \\
\mathrm{CC}_{50}\end{array}$} \\
\hline & $\mathrm{CC}_{50}$ & SI & $\mathrm{CC}_{50}$ & SI & $\mathrm{CC}_{50}$ & SI & \\
\hline CG-1 & 249.8 & - & 533.3 & - & 8.9 & - & NT \\
\hline CG-2A & 20.6 & - & 19.6 & - & 6.9 & - & NT \\
\hline CG-2B & 136.9 & - & 140.4 & - & 13.1 & - & NT \\
\hline 1 & $36.2 \pm 5.1$ & 2.8 & $46.9 \pm 9.2$ & 2.1 & $389.0 \pm 10.9$ & 0.2 & $103.1 \pm 1.8$ \\
\hline 2 & NA & - & $56.0 \pm 2.1$ & 2.3 & $68.7 \pm 3.4$ & 1.9 & $131.2 \pm 3.2$ \\
\hline $1 \mathrm{a}$ & NT & & NT & & NT & & NT \\
\hline $2 a$ & NT & & NT & & NT & & NT \\
\hline 3 & $67.7 \pm 10.2$ & 1.4 & $35.2 \pm 3.2$ & 2.8 & $54.5 \pm 3.6$ & 1.8 & $98.6 \pm 1.2$ \\
\hline 4 & $15.5 \pm 4.7$ & 9.3 & $43.3 \pm 4.2$ & 3.3 & $174.6 \pm 2.1$ & 0.8 & $145.0 \pm 2.9$ \\
\hline 5 & $43.9 \pm 3.9$ & 4.5 & $66.1 \pm 7.2$ & 3.0 & $179.5 \pm 2.1$ & 1.1 & $199.1 \pm 2.7$ \\
\hline 6 & $69.3 \pm 4.2$ & 7.5 & $86.8 \pm 11.3$ & 6.0 & $102.7 \pm 4.1$ & 5.0 & $521.0 \pm 6.3$ \\
\hline $6 a$ & $120.5 \pm 9.1$ & 1.0 & $46.0 \pm 2.1$ & 2.6 & $65.7 \pm 3.4$ & 1.8 & $123.8 \pm 4.2$ \\
\hline Docetaxel & $0.20 \pm 0.01$ & 5.5 & $0.23 \pm 0.03$ & 4.7 & $0.08 \pm 0.01$ & 13.7 & $1.1 \pm 0.05$ \\
\hline
\end{tabular}

SI: selectivity index were calculated as the ratio $\mathrm{CC}_{50}$ of VERO cells/CC $\mathrm{C}_{50}$ of each cell line; $\mathrm{CG}-1$ : crude extract of $C$. greggii; $\mathrm{CG}-2 \mathrm{~A}$ : low polarity fraction; CG-2B: medium polarity fraction

Table S5. Inhibition of the growth $\left[\mathrm{IG}_{50}(\mu \mathrm{g} \mathrm{mL}-1)\right]$ in HeLa, KB, HEp-2 and VERO cells of compounds 1-6 from C. greggii, and derivative 6a

\begin{tabular}{lcccc}
\hline Compound & \multicolumn{2}{c}{ Antiproliferative activity } & HEp-2 & VERO \\
\hline $\mathbf{1}$ & HeLa & KB & $70.2 \pm 4.5$ & $146.8 \pm 6.7$ \\
$\mathbf{2}$ & $192.3 \pm 2.4$ & $45.0 \pm 4.5$ & $53.6 \pm 5.6$ & $189.7 \pm 5.2$ \\
$\mathbf{3}$ & $141.9 \pm 1.6$ & $55.4 \pm 5.6$ & $89.8 \pm 4.9$ & $89.2 \pm 2.1$ \\
$\mathbf{4}$ & $48.8 \pm 3.1$ & $33.8 \pm 3.1$ & $152.4 \pm 3.2$ & $221.5 \pm 5.6$ \\
$\mathbf{5}$ & $107.7 \pm 1.2$ & $46.0 \pm 4.5$ & $140.0 \pm 2.5$ & $201.4 \pm 3.8$ \\
$\mathbf{6}$ & $125.4 \pm 2.3$ & $56.9 \pm 3.4$ & $98.4 \pm 2.8$ & $351.0 \pm 8.9$ \\
$\mathbf{6 a}$ & $73.9 \pm 2.9$ & $66.6 \pm 7.8$ & $44.7 \pm 5.6$ & $143.5 \pm 6.2$ \\
Docetaxel & $55.9 \pm 2.5$ & $19.22 \pm 2.3$ & $0.06 \pm 0.02$ & $0.11 \pm 0.02$ \\
\hline
\end{tabular}

